\title{
IMPACT OF FADAMA-III CAPACITY BUILDING AND RURAL INFRASTRUCTURE ON AGROPRENEURS BUSINESS DEVELOPMENT
}

\author{
Aderonke Agnes Oyeniyi \\ Osun state University, Osogbo, Nigeria \\ agnes.oyeniyi@uniosun.edu.ng \\ Kanyinsola Helen Cole \\ University of Ibadan, Oyo, Nigeria \\ oyin.helencole@gmail.com
}

\begin{abstract}
The broad objective of the study is to examine the impact of Nigeria Fadama National development project on Agropreneur's business development in Osun state, Nigeria. The sample size selected was Two hundred and seventy (270). Multi-stage sampling was adopted, and Simple random sampling design was used. Data collection method was a close-ended questionnaire. Linear Regression, Multiple Regression and Anova were used to test the Hypotheses of the study. The study shows that rural infrastructure variables used in the selected study area significantly predicted the level of Business Development, $F(1,268)=30.413, p<0.05 F-$ statistical indicates that the overall regression model is highly statistically significant in terms of its goodness of fit since the value of $F_{\text {tab }}$ $(1,268)>F_{\text {cal }}(30.413)$. It also shows the magnitude of the difference, since the sig level is greater than 0.05 i.e $0.811,0.985$. The study reveals that only 0.9 per cent variance exists between the selected genders. In conclusion capacity building has really assisted farmers in adopting new technology in farming which led to an increase and expansion of their business outlets. The study recommends: Regular training for farmers to discover their skills in diversifying into various businesses within the agricultural sector using new technology should be encouraged by all stakeholders in business of food security and provision of grants to enable them expand their business desires.

Keywords: Agropreneurs, development, project, farmers, infrastructure \& business

DOI: https://doi.org/10.24818/beman/2021.11.1-01
\end{abstract}

\section{INTRODUCTION}

It is observed that doing business is as old as man. Entrepreneurship is the lifeblood of any growing economy; it is the mainstay of the economy. Ogundele (2015) stated that entrepreneurship is a perceptiveness to change the entrepreneur as one who always searches for change, responds to and exploits opportunity. According to Imafidon (2014) entrepreneurship activities and innovative ingenuity in Nigeria have developed enterprises in the area of foodstuff, restaurants, Fast food ranching, 
quarrying, repairs of G.S.M accessories and the printing and selling of recharge cards and tools fabrications.

In recent times, it is observed that there is growing misconceptions of which entrepreneurs are, not just people that buy and sell things. It is not limited to the combination of the factors of production to meet the human need at a profit. There are various types of entrepreneurs. They exist in all sectors of the economy. They could operate as Intrapreneurs, Edupreneurs, Technopreneurs, Business Entrepreneurs, trading entrepreneurs, social entrepreneurs, Industrial Entrepreneurs, consultant Entrepreneur, Corporate Entrepreneurs and Agropreneurs, which is the main focus of the study.

Yusoff, Ahmad and Abdul-Halim (2019) affirmed that scholars and policymakers had shifted attention from work on small agricultural production by farmers to practices that will add value to agricultural produce. To enhance farm producers income as opposed to just pushing the raw produce to the market which put them at the mercy of middlemen and marketers that offer poor produce prices, thereby leading to farmers poor produces process, thereby loading to farmers poor condition and most of the time subjecting these farmers to perpetually poor standard living.

The various Agricultural value addition practices, when put into practice by farmers (That is Agropreneurs) through the intervention of researchers/extensionists, social workers and backed by loans or grants either from governments, bank or through cooperative societies, will eventually lead to increased wealth generation, increased profit and a higher standard of living to these Agropreneurs.

Fadama III and Fadama III Additional funding (Fadama III AF) was instituted by the Federal Government, World Bank and state/local governments to assist farmers in producing larger volume/quantity of produced by cultivating greater Hectares, of various food crops, increased livestock, Agro-processing, storage, creating market shops in their vicinity, accessing more significant markets and distribution outlets for both inputs like Agrochemicals, spraying Pumps, fertilizers and semi-finished products that are capable of prolonging the shelf life's of these products to attract higher market prices. Examples include converting raw cassava tubers into fried guarri grain packaged in neat polyethylene bags, soybeans to soymilk or soy cakes among others.

In line with the various definitions given by different scholars quoted above, Agropreneurship can be seen as commercialization of agricultural knowledge, skills and practices. These practices include activities related to the production, processing, storage, distribution, marketing and transportation of Agricultural produce to appropriate market outlets to generate income. It means that the Agropreneur will expand his or her production of the particular commodities beyond the subsistence level, which the Fadama projects were set up to encourage and achieve. 


\section{Oyeniyi A.A \& Cole K.H \\ IMPACT OF FADAMA-III CAPACITY BUILDING AND RURAL INFRASTRUCTURE ON AGROPRENEURS BUSINESS DEVELOPMENT}

Agriculture should be the mainstay of any economy as it is difficult to survive without food. Agriculture is, therefore, the lifeblood of any nation. One would wonder why it is so. The reduction in the supply of food against demand could lead to early grave of people in the country. The concept of food security, as explained by lbitoye (2014) is to ensure that the household can obtain adequate food either through home production or through purchase. Therefore, to reduce the rate of household food insecurity, will entail increasing access to productive resources such as land, labour, inputs and credits as well.

Nigeria is therefore blessed with productive factors that should enhance effectiveness and efficiency in this sector as mentioned above. There are vast acres of land and vegetations, but it's been underutilized. It is also observed that most young minds do not want to take up Agriculture as their means of livelihood. The reason is unknown; speculations have been made for the disinterest of people in the industry. Amongst which include lack of incentives, lack of access to information, obsolete technology, poor social amenities, and lack of a link to foreign bodies, among others.

\subsection{Objectives of the study}

The broad objective of the study is to examine the impact of Nigeria Fadama National development project on Agropreneur's business development in Osun state, Nigeria. Other objectives are to:

i. assess the impact of rural infrastructure (Road, electricity and health) on Agropreneur's business development.

ii. investigate the significant between capacity development and business performance among male and female entrepreneurs in the project.

\subsection{Research Hypotheses}

Ho1: Rural infrastructure does not have a significant impact on Agropreneur's business development. $\mathrm{H}_{02}$ : There is no significant difference between capacity building and Agropreneur's business performance among Male and Female beneficiaries

\section{LITERATURE REVIEW}

\subsection{Concept of Business Development}

It is a concept that can be defined from different perspectives which may include a socio-economic system that can occur in parts at a different pace and driven by various forces. According to Bellu (2011), development means an event constituting a new stage in changing situation or the process of change par/se. This informs that development is always jeered towards positive results on something. According to Bizimana et al. (2016) business development comprises of several tasks and processes generally aiming at developing and implementing growth opportunities between organizations. It is a 
subset of the fields of business, commerce and organizational theory. Business development is the creation of long -term value for an organization from customers, markets and relationship.

Bizimana et.al. (2016) asserted that the financial and non-financial criteria could measure business development. Traditional measures of business development have been based on either employee numbers or financial performance such as profit, turn over or return on investment. However, the yardstick for measuring business development vary from one business owner to another due to the success of their businesses ranging from reliable suppliers, meaningful relationship with other entrepreneurs, loyal customers and clientele. The frequency of interaction and patronage is also very relevant. It is needful to know that for any business to develop the capability of the owner is very vital since every action and decision revolves around him either as owner-manager or manager.

In a society or economic system, development is usually seen or referred to as something getting better from one stage to another. It comes about due to deliberate action that is carried out by an agent or some authority empowered to bring about improvement to favorable circumstances in all; this includes developing policies and private investments in diverse forms, though it's a complex whole which has interdependent parts, that means if a part is affected, it will affect the other parts. This suffices to say that Fadama is conceptualized as a practice that can lead to tremendous development which usually leads to increasing production and consequently increased income of the participants, thereby raising their standard of living. This will, in turn, increase the economy leading to an increase in Gross Domestic Product (GDP) of the nation.

The success of Fadama I and II centred mainly on under irrigation during the dry season or in low land areas where the water table is high, but Fadama III -AF has expanded the scope of operation under Fadama I and II to include Agro-processing, production of livestock feeds, livestock especially small ruminates, poultry, piggery and marketing of the semi-finished products, including marketing of agroinputs like agrochemicals, feeds and fertilizers. Training of beneficiaries in Fadama project is part of the development adopted to improve the efficiency of recipients, in production, processing and marketing. It fits perfectly well to economic growth that is, improvement of the way endowment, goods and services are used within the Fadama beneficiaries' groups to generate new products and services for Additional consumption and investment opportunities to the environment at large. It is in this light that Fadama IIIAF financing was supported by states that are participating in Fadama Projects Gladly welcome the idea of Additional Financing having recorded tremendous success in Fadama I, II and III. Adubi (2014) stated that additional financing came up to support a critical transformation agenda by improving farmer's productivity and performance of clusters of farmers who engage in staple food products such as rice, cassava, sorghum and horticulture with high potentials in the selected states. Although He corroborated 


\section{Oyeniyi A.A \& Cole K.H \\ IMPACT OF FADAMA-III CAPACITY BUILDING AND RURAL INFRASTRUCTURE ON AGROPRENEURS BUSINESS DEVELOPMENT}

further that Fadama III Additional funding is aimed at making sure that everything is done to make crop production in the affected countries is increased and farmers are connected to up-takers in the additional financing. It suffices to say that there are improvement and development over what has been on the ground. Supporting this assertion, Yahaya (2014) opined that Fadama III has not only transformed the lives of farmers but also stands out as leading light among Agricultural projects.

\subsection{Rural Infrastructure (Road, Electricity \& Health)}

Aidah (2013), defines training as the planned and systematic modification of behaviour through learning events, activities and programmes which result in participants achieving the levels of knowledge, skills, competencies and abilities to carry out their work effectively. Olatinwo (2005) corroborated this assertion that training in a wider perspective can be seen as a factor ensuring that every individual employee either in government or in private industrial, commercial/ business institution possesses the required knowledge skill and attitude to effectively perform assigned duties, and not merely an instrument for adjustment of young people work environment. This suffices to mean that there is need for training of Farmers/Fadama beneficiaries in the use of modern technology and application of chemicals where necessary to be impacted by the recognized extension agents in the Fadama project. Training can be viewed as a growing gap between existing competencies and skills, and such competencies and skills are to meet future challenges. Exercise plays a vital role in the Fadama beneficiary's productivity and business development. It is potent to their effectiveness and efficiency. No wonder that farmers who are exposed to the training of the use of modern tools, equipment and technology tend to perform better which in turn increase their productivity and expansion of the Agrobusiness (Adesoji et al., 2006).

Extension agents engage in a peculiar assignment which has to do with training and retraining of farmers to contribute to enlarging the capacity of farmers. Hence, the need for the beneficiaries to participate from time to time since training is one of the conditions for the Fadama project. In support of the above assertion, Uwaifo (2011) affirmed that capacity training unlocks the door of modernization, but it is the trainer that holds the key to the door. He stressed further that trainers are the hub or pivot on which any successful farming program revolves. If trainers perform their tasks dutifully, there will be certainly a myriad of new technologies, innovations and creativity in the future of Agro-business.

In support of this assertion, Ugochukwu and Ogbaekirigwu (2014) opined that training is a continuous exercise to ensure consistent improvement in the quality of their output and that the practice is in two folds: training to acquire minimum skill for Agricultural activities. It always helps to keep abreast of new challenges in the farming activities and to be relevant. The fact remains that, what one does not have, he cannot give to someone else, which means training is critical to avoid the blind leading another blind. 


\subsection{Capacity Building}

Capacity building is part of an organizational strategy to improve overall productivity, motivate career center staff to deliver high-quality services and create an ongoing commitment to innovation and system improvement. In view of this perspective, staff training is an integral part of a more significant human resource investment.

\subsubsection{Scope of Capacity Building}

Akinlotan (2011) stated that capacity building covers the following areas:

i. Training

ii. Setting up of institutions

iii. Utilization and retention managerial, professional technical personnel in the public and private sector of the economy

It suggests that capacity building for service delivery as it affects Agriculture Industry; the scope should be 'total'. The Agro-industry is all out to improve food security at a profit and enhance the output of farmers. As they make use of their intellect, they must also have the right attitude to be able to acquire skills correctly and relate well in their professional callings.

\subsubsection{Forms of Capacity Building}

Capacity building can take any of the following ways

a. Country-specific

b. Program/project-specific

c. Organizational - related

d. Job/ task-specific - related

However, the peculiarity of each country, organization and job should be considered to determine the relevant one.

\subsection{Capacity Building in the Agricultural Industry}

Akinlotan (2011) stated the relationship between capacity building in the Agricultural industry and should be designed to address the followings:

a. Identifying human performance gaps

b. Develop and implement appropriate interventions to avert the designated gaps

c. Conduct research in the critical sectors of technology delivery

d. Collaborate with other agencies both local and international bodies

Having good capacity building program in place for Agropreneurs, farmer/ Fadama project beneficiaries will have adequate and relevant knowledge, especially new technology and advancements. 


\section{Oyeniyi A.A \& Cole K.H \\ IMPACT OF FADAMA-III CAPACITY BUILDING AND RURAL INFRASTRUCTURE ON AGROPRENEURS BUSINESS DEVELOPMENT}

Challenges of Effective Capacity Building as stated by Akinlotan (2011) include:

i. Effective capacity building is not void of challenges which include:

ii. Non-existence of adequate training policy

iii. Inadequate funding

iv. Lack of shared understanding of the importance of capacity building

v. Lack of belief in the bulk of training and knowledge transfer by the extension agents

vi. Impact of globalization

vii. Orientation to training

viii. Training cost

ix. Mismanagement of funds and corruption

$\mathrm{x}$. Dwindling external support for capacity building

\subsection{Business Development}

Bellu (2011) affirmed that development is an event constituting a new stage in changing situation or process of change parse. It suggests that growth is meant to be tailored towards having to enhance the positive effect on something. Ajulor (2017) considers that development is a multi-dimensional process which involves re-organizing and re-orientating the socio-economic order. While economic growth could be seen as the eradication of poverty, inequality, and unemployment and increase the standard of living within a growing economy.

Although development as viewed from another perspective (Olaiya, 1998), is a process of providing opportunities for improving competence and performance. It is also applicable to business practices which require understanding the nitty-gritty of the business. A competent entrepreneur will be able to make decisive decisions when taking the risk of starting a business. Kadiri et al., 2017 affirmed that motivated young people to need the right set of skills to identify opportunities and turn their entrepreneurial projects into successful ventures. Therefore, entrepreneurial competence development has been acknowledged to be essential in any business development. Business development requires competence which is linked with making use of creative potentials, intellectual capacities, and leadership capabilities both for personal growth and economic growth.

A vital developmental process is necessary for business which includes planning, promotion, production and product. It is corroborated by Bizimana, et al (2016), who posited that business development comprises of a member of task and processes generally aimed at building and implementing growth opportunities between organizations, it was stated further that the financial and non-financial criteria can measure business development. This suffices that the event is tied to the advancement of a particular situation. 


\section{METHODOLOGY}

The study employed both descriptive, regression and Anova statistics. Hypothesis one was tested using multiple regression and Hypothesis Two was tested using Anova. The study adopted simple random sampling technique. First stage was purposive selection of Osun West Senatorial District which comprises of ten (10) Local Government Areas (LGAs). Second stage was random selection of two Local Governments from Osun West Senatorial District.

The third stage was purposive selection of Agropreneurs Fadama Users Group (FFUGs), and the fourth stage was random selection of beneficiaries (Male and Female Agropreneurs) of Fadama project. The research instrument that was used for this study is a structured questionnaire. The questionnaire was used in collecting the data for the study.

Iwo and Ede North Local Government was selected because of their involvement in Agro-processing and livestock and they are still viable while other Fadama users in other local governments have not been able to manage their program effectively, hence, have become moribund.

TABLE 1: TOTAL NUMBER OF FADAMA PARTICIPANTS IN IWO AND EDE NORTH

\begin{tabular}{|l|l|c|c|}
\hline S/N & Fadama Users & Male & Female \\
\hline 1 & Iwo & 136 & 153 \\
\hline 2 & Ede North & 264 & 276 \\
\hline & Total & 400 & $\mathbf{4 2 9}$ \\
\hline
\end{tabular}

Source: Researcher conceptualization

The sample and sampling technique which was used for this research is Taro Yamane (1973):

$\mathrm{n}=\mathrm{N}$

$$
1+\mathrm{N}\left(\mathrm{e}^{2}\right)
$$

Where $n=$ sample size

$\mathrm{N}=$ population

$\mathrm{e}=$ level of significance

$\mathrm{N}=829$ participants

$e=0.05$ or $5 \%$

$\mathrm{n}=829$

$1+829(0.05)^{2}$

$=829$

$$
1+829(0.0025)
$$




$$
\begin{aligned}
& n=\frac{829}{1+2.075} \\
& n=\frac{829}{3.075}
\end{aligned}
$$

$n=269.5 ; n=270$ was considered as respondents for this study

\subsection{Operationalization}

The regression and Anova model are specified explicitly as follows:

Hypothesis One: $Y=\beta_{0}+\beta_{3} X_{3}+\beta_{4} x_{4}+\beta_{5} x_{5}+u \ldots \ldots \ldots$ (Multiple regression)

$Y=\beta_{0}$ (constant) $+\beta_{3} x_{3}($ good road $)+\beta_{4} X_{4}$ (Healthcare) $+\beta_{5} X_{5}$ (Electricty) $+u$

Hypothesis Two: $Y=\beta_{0}+\beta_{6} X_{6}+u$ ...(Anova)

$Y=\beta_{0}$ (Constant) $+\beta_{6} X_{6}$ (capacity building) $+u$

\section{RESULTS}

Hypothesis One: Rural infrastructure does not have significant impact on Agropreneur's business

\begin{tabular}{|c|c|c|c|c|}
\hline Model & $\mathbf{R}$ & $\mathbf{R}^{2}$ & Adjusted $\mathrm{R}^{2}$ & Std. Error of the Estimate \\
\hline 1 & $.732^{\mathrm{a}}$ & .536 & .499 & 1.552 \\
\hline
\end{tabular}
development.

The model summary Table $2 a$ gives $R^{2}$ value $=(0.536)$. This shows that rural infrastructure, have positive influence on business development. Thus, this model is predicting $53.6 \%$ of the variance in the level of business development pooling all factors together simultaneously; meaning that $54 \%$ of the variance is determined by the predictors captured in this model. Hence, the study concludes that rural infrastructure has positive effect on business development. The level of business devilment can be predicted from various rural infrastructure captured in this study.

TABLE 2B: MULTIPLE REGRESSION ANALYSIS SHOWING SIGNIFICANCE OF PREDICTORS ON THE RURAL INFRASTRUCTURE.

\begin{tabular}{lllccl}
\hline Model & Sum of Square & df & Mean Square & F & Sig \\
\hline Regression & 73.299 & 1 & 73.299 & 30.413 & $.000^{\mathrm{b}}$ \\
Residual & 643.489 & 267 & 2.410 & & \\
Total & 716.788 & 268 & & & \\
\hline
\end{tabular}

${ }^{*} p<0.05 \quad$ a. Dependent Variable: Business Development

Source: Author's Computation using SPSS 20.0 
Table $2 \mathrm{~b}$ shows that rural infrastructure variables used in the selected study area significantly predicted the level of Business Development, $F(1,268)=30.413, p<0.05 \mathrm{~F}$ - statistical indicates that the overall regression model is highly statistically significant in terms of its goodness of fit since the value of $F_{\text {tab }}$ $(1,268)>F_{\text {cal }}(30.413)$. Therefore, the study concludes that rural infrastructure contributes to Business Development in selected study area.

TABLE 2C: CONTRIBUTION OF EACH PREDICTOR ON BUSINESS DEVELOPMENT VARIABLES.

\begin{tabular}{|c|c|c|c|c|c|c|c|c|c|}
\hline \multirow[t]{2}{*}{ Model } & \multicolumn{2}{|c|}{$\begin{array}{l}\text { Unstandardized } \\
\text { Coefficients }\end{array}$} & \multirow{2}{*}{\begin{tabular}{|c|}
$\begin{array}{c}\text { Standardized } \\
\text { Coefficients }\end{array}$ \\
Beta
\end{tabular}} & \multirow[t]{2}{*}{$T$} & \multirow[t]{2}{*}{ Sig. } & \multicolumn{2}{|c|}{$\begin{array}{c}95.0 \% \\
\text { Confidence } \\
\text { Interval for B }\end{array}$} & \multicolumn{2}{|c|}{$\begin{array}{l}\text { Collinearity } \\
\text { Statistics }\end{array}$} \\
\hline & $B$ & $\begin{array}{l}\text { Std. } \\
\text { Error }\end{array}$ & & & & $\begin{array}{l}\text { Lower } \\
\text { Bound }\end{array}$ & $\begin{array}{l}\text { Upper } \\
\text { Bound }\end{array}$ & $\begin{array}{c}\text { Toleranc } \\
\mathrm{e}\end{array}$ & VIF \\
\hline (Constant) & 4.984 & .408 & & 12.201 & .000 & 4.179 & 5.788 & & \\
\hline $\begin{array}{l}\text { Rural } \\
\text { Infrastructure }\end{array}$ & .188 & .034 & .320 & 5.515 & .000 & .121 & .254 & 1.000 & 1.000 \\
\hline
\end{tabular}

a. Dependent Variable: Business Development

Source: Author's Computation using SPSS 20.0

Table $2 c$ shows the contribution of the predictors. In this case, Rural Infrastructure contributes with Beta value $=.320, p<.05$ and $t$-value $=5.515$. The contribution is statistically significant to the level of Business Development. Hence, the study concludes that Rural Infrastructure has positive effects on Business Development of selected study area.

Hypothesis Two: There is no significant difference between capacity building (Training funding) and Agropreneur's business performance among Male and Female beneficiaries.

TABLE 3A. GROUP STATISTICS Group Statistics

\begin{tabular}{|c|c|c|c|c|c|c|c|}
\hline \multirow{2}{*}{\multicolumn{8}{|c|}{ Group Statistics }} \\
\hline & & & & & & & \\
\hline & \multirow{3}{*}{\multicolumn{2}{|c|}{$\begin{array}{l}\text { Gender of } \\
\text { respondents }\end{array}$}} & \multirow[t]{3}{*}{ Statistic } & \multicolumn{4}{|c|}{ Bootstrapa } \\
\hline & & & & \multirow[t]{2}{*}{ Bias } & \multirow[t]{2}{*}{ Std. Error } & \multicolumn{2}{|c|}{$\begin{array}{l}95 \% \text { Confidence } \\
\text { Interval }\end{array}$} \\
\hline & & & & & & Lower & Upper \\
\hline \multirow{8}{*}{$\begin{array}{l}\text { Capacity } \\
\text { Building } \\
\text { (Training } \\
\text { funding) }\end{array}$} & \multirow[t]{4}{*}{ Female } & $\mathrm{N}$ & 111 & & & & \\
\hline & & Mean & 12.40 & .01 & .17 & 12.06 & 12.73 \\
\hline & & $\begin{array}{c}\text { Std. } \\
\text { Deviation }\end{array}$ & 1.820 & -.039 & .261 & 1.299 & 2.288 \\
\hline & & $\begin{array}{l}\text { Std. Error } \\
\text { Mean }\end{array}$ & .173 & & & & \\
\hline & \multirow[t]{4}{*}{ Male } & $\mathrm{N}$ & 158 & & & & \\
\hline & & Mean & 12.22 & .00 & .14 & 11.95 & 12.47 \\
\hline & & $\begin{array}{c}\text { Std. } \\
\text { Deviation }\end{array}$ & 1.698 & -.007 & .122 & 1.468 & 1.929 \\
\hline & & $\begin{array}{l}\text { Std. Error } \\
\text { Mean }\end{array}$ & .135 & & & & \\
\hline Business & Female & $\mathrm{N}$ & 111 & & & & \\
\hline
\end{tabular}




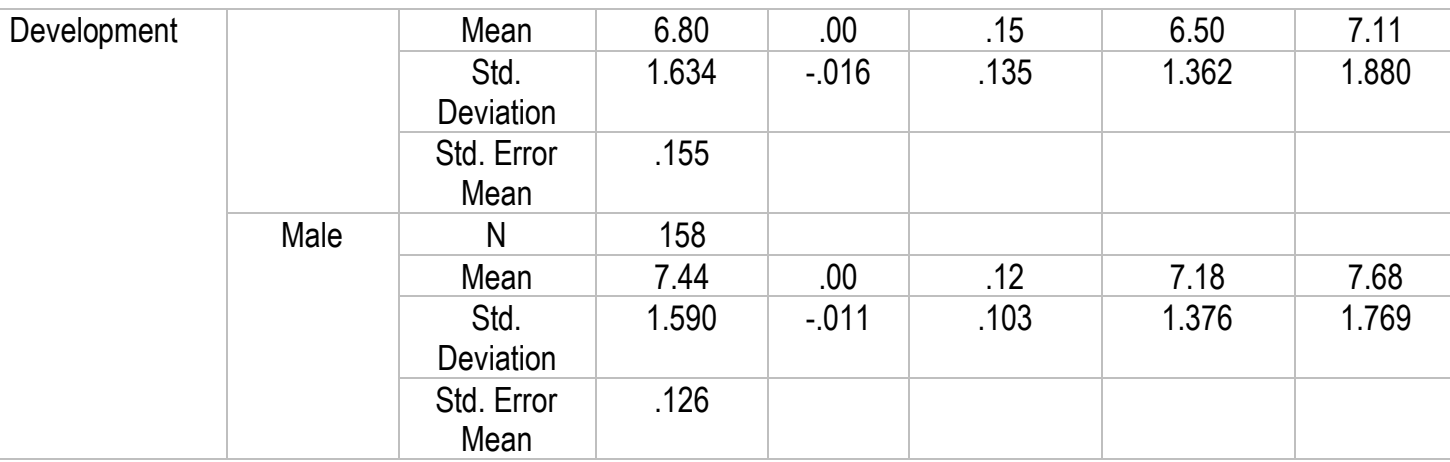

a. Unless otherwise noted, bootstrap results are based on 1000 stratified bootstrap samples

Source: Author's Computation SPSS

Table 3a reveals the results of Levene's test for equality of variance (variability) of mean score between the two groups (Male and Female Agropreneur's), that group 1 (Female) the mean of 12.40 with standard deviation of 1.820 , error mean shows 0.173 while group 2(Male) the mean value of 12.22 with standard deviation revealed 1.698 with difference of 0.001 . The error mean term is 0.135 , the error term value are both less than 0.1 which is 10 percent. The value of sig is $>$ than 0.05 , this mean there is no significant difference between the two groups under this study.

TABLE 3B. INDEPENDENT SAMPLES TEST
Levene's Test
t-test for Equality of Means

for Equality of

Variances

\begin{tabular}{|c|c|c|c|c|c|c|c|c|c|}
\hline & \multicolumn{2}{|c|}{$\begin{array}{l}\text { Levene's Test } \\
\text { for Equality of } \\
\text { Variances }\end{array}$} & \multicolumn{7}{|c|}{ t-test for Equality of Means } \\
\hline & \multirow[t]{2}{*}{$F$} & \multirow[t]{2}{*}{ Sig } & \multirow[t]{2}{*}{$T$} & \multirow[t]{2}{*}{ df } & \multirow[t]{2}{*}{ Sig. } & \multirow[t]{2}{*}{$\begin{array}{l}\text { Mean } \\
\text { Differen } \\
\text { ce }\end{array}$} & \multirow{2}{*}{$\begin{array}{c}\text { Std. } \\
\text { Error } \\
\text { Differen } \\
\text { ce }\end{array}$} & \multicolumn{2}{|c|}{$\begin{array}{l}95 \% \text { Confidence } \\
\text { Interval of the } \\
\text { Difference }\end{array}$} \\
\hline & & & & & & & & Lower & Upper \\
\hline $\begin{array}{l}\text { Equal } \\
\text { variances } \\
\text { assumed }\end{array}$ & .057 & 811 & .836 & 267 & .404 & 181 & .217 & -.245 & .608 \\
\hline $\begin{array}{l}\text { Equal } \\
\text { variances } \\
\text { not } \\
\text { assumed }\end{array}$ & & & .826 & $\begin{array}{l}226 . \\
321\end{array}$ & .410 & .181 & .219 & -.251 & .613 \\
\hline $\begin{array}{l}\text { Equal } \\
\text { variances } \\
\text { assumed }\end{array}$ & .000 & 985 & -3.188 & 267 & .002 & -.635 & 199 & -1.027 & -.243 \\
\hline $\begin{array}{l}\text { Equal } \\
\text { variances } \\
\text { not } \\
\text { assumed }\end{array}$ & & & -3.173 & $\begin{array}{l}232 . \\
840\end{array}$ & .002 & -635 & .200 & -1.029 & -241 \\
\hline
\end{tabular}

\section{Capacity}

Building

(Training

funding)

Busines

$s$

Develop

ment

Source: Author's Computation using SPSS

Also, the table $3 b$ shows the magnitude of the difference, since the sig level is greater than 0.05 i.e $0.811,0.985$ therefore the first line in the table will be used i.e Equal variances assumed. In this case the assumption of equal variances has not been violated. 
Eta-Square formula

$$
=\frac{t^{2}}{\left(t^{2}+N 1+N 2-2\right)}
$$

Where $\mathrm{t}=3.188, \mathrm{~N} 1=111$, and $\mathrm{N} 2=158$

$=\underline{3.188^{2}}$

$\left(3.188^{2}+111+158-2\right)=$

$=\underline{10.163344}$

$10.163344+267$

Eta square $=.0091$ percent.

Based on this report, the study reveals that only 0.9 percent variance exists between the selected genders. The magnitude of the variance is very small. The study therefore accepts null hypothesis that there is no significant difference between capacity building (training funding) and Agropreneur's Business development among the entrepreneur in the selected study area.

\section{DISCUSSION}

According to Manggat et al. (2018), infrastructural development is key in rural areas and requires collaboration and integration between all related parties this is essential especially in the Fadama III project which is practiced in groups in connection with other stakeholders. Egbetokun (2009) and Manggat et al. (2018) corroborated that infrastructure is an integral part of rural community's development strategies because infrastructural development is integrated with all other aspects such as agriculture, education, health, nutrition, electricity.

In another view African Monitor (2012) posited that there is huge rural infrastructure back log resulting from decades of under investment lack of maintenance and destruction and dilapidation due to conflicts. The quality of infrastructure is generally poor and infrastructure service costs are relatively high. This suggests that government intervention is germane in Fadama project to achieve required success since some of the needed infrastructure cannot be provided by the Local farmers and where they apply communal effort to have some, the quality may not be of standard which they can enjoy for a long period.

\section{CONCLUSIONS}

The level of Agropreneur's business development can be predicted from various training (extension agents) captured in this study, Rural infrastructure has positive effect on business development. Therefore, the following recommendations are suggested: 


\section{Oyeniyi A.A \& Cole K.H \\ IMPACT OF FADAMA-III CAPACITY BUILDING AND RURAL INFRASTRUCTURE ON AGROPRENEURS BUSINESS DEVELOPMENT}

$>$ Based on the result obtained from the study, which revealed that infrastructures like good roads, electricity and good health care delivery play positive roles in Agropreneurs business development, it is recommended that the Fadama group users (FUGs) should always maintain the infrastructure well and utilize the facilities provided by government to assist them in doing their Agro-businesses efficiently and effectively without stress.

$>$ The study also accepts null hypothesis that there is no significant difference between capacity building (training, funding) and Agropreneur's Business development among the entrepreneur in the selected study area. Therefore, Training should be given to Agropreneurs to foster productivity.

Some constraints that limited the study includes unavailability of participants, insufficient literature review and the scheme (Fadama) is not active anymore.

\section{REFERENCES}

Adesoji, S. A., Farinde, A. J., \& Ajayi, O. A. (2006). Assessment of the training needs of fadama farmers for future agricultural extension work development in Osun State, Nigeria. Journal of Applied Sciences, 6(15), 3089-3095.

Adubi, A. (2014)."Third National Development Project Additional Financing Fadama III-AFNews". A Quarterly News Letter of National Fadama Coordination office, Abuja. 6-7.

African Monitor (2012) Rural infrastructure in Africa. Development support Monitor. 1. 20 - 21.

Aidah, N (2013) "Effects of Training on Employee Performance." University of Applied Sciences. International Business.

Ajulor, O.V. (2017). "Government policies and Entrepreneurship development in Nigeria". The entrepreneur A Book of Readings in Honour of Late Professor Sunday 0. Otokiti. Department of Business and Entrepreneurship, Kwara state University, Malete, Nigeria. 2. 137 -149.

Akinlotan, J.A (2011) Challenges of Human Capacity Building in a Developing Economy. Paper Delivered at the Industrial Training Fund Center for Excellence Bukuru Jos. 1 - 5.

Bellu, L. G. (2011). Development and development paradigms: A (reasoned) review of prevailing visions. Easypol module, 102.

Bizimana C., Mbabazi, P., Mbabazize, Twesige, D. (2016). Effect of Guarantee Fund On The Business Development In Rwanda. A Case Study of Guarantee Fund Beneficiaries Banque Du Rwanda Itd. European Journal of Business and social Sciences, 5 (8) 95-109.

Egbetokun, O.A (2009). Provision Rural Infrastructures in Oyo state of Nigeria. Journal of Agricultural sustainable practice, 1 (2), $69-70$

Ibitoye, C.B. (2014). Role of Fadama III Project In Empowering Fadama Women Farmers Toward Attaining Food Security In Benue state, Nigeria. Msc Thesis Submitted to School of Post Graduate Studies, Ahamadu Bello University Zaria 9-15.

Imafidon, K. (2014). Entrepreneurship development for sustaining economic growth in third world nations. Journal of Emerging Trends in Economics and Management Sciences, 5(7), 101-108. 
Kadiri, Abu Zekeri and Adebayo Phillip, (2017). Drivers of youth Entrepreneurial opportunities in Micro small IT enterprises: A conceptual analysis. International Journal of entrepreneurship innovation and management. 2 (2 \& 3), $160-166$

Manggat, I., Zain, R., \& Jamaluddin, Z. (2018). The impact of infrastructure development on rural communities: A literature review. International Joumal of Academic Research in Business and Social Sciences, 8(1), 647-658.

Ogundele, O.J.K. (2015) Conceptual Clarifications. The Entrepreneur. A Book of Readings in Honour of Late Professor Sunday. O. Otokiti. Department of Business and Entrepreneurship, Kwara State University, Malete, Nigeria. 1, 1 - 34

Olaiya, S.A. (1998). Training for industrial development in Nigeria. Ehindero Nig. LTD. 2 (24 - 30)

Olatinwo, I.O (2005). Training for Results. An Organizational strategy. Lagos Printing press. $13-20$

Ugochukwu C.O and Ogbaekirigwu (2014) 'Entrepreneurship Development Through Vocational Education Training: Issues and Roles in Skills Acquisition and Manpower Development in a Developing Economy. Journal of Educational policy and Entrepreneurial Research. (JEPER) 1(2) $151-157$

Uwaifo, V. O. (2011). The 21st century challenges of technical education in Nigeria. J. Res. Edu. Soc, 2(1), 106-112.

Yahaya, Kuta (2014) Fadama III-AF Assured of Niger states support. Making a Remark during World Bank. FGN Mission in Fadama-A-F News. A quarterly Newsletter of National Fadama coordination office Abuja. 6 -7

Yamane, T. (1973). Statistics: an introductory analysis - 3.

Yusoff, A., Ahmad, N. H., \& Abdul Halim, H. (2019). Unravelling agropreneurship activities among Malaysian Gen Y: Social institutional factors as enablers. International Journal of Entrepreneurial Behaviour and Research, 25(3), 457-479. 